\title{
ФУНКЦІОНАЛЬНІ ЗМІНИ СЕРЦЕВО-СУДИННОЇ ДІЯЛЬНОСТІ В УЧНІВ ІЗ ПОРУШЕННЯМИ ПОСТАВИ ДО ТА ПІСЛЯ КОРЕКЦІї
}

\author{
Т. П. Андрухів, С. О. Коноваленко \\ Чортківська центральна комунальна районна лікарня \\ ДВНЗ «Тернопільський державний медичний університет \\ імені І. Я. Горбачевського МОЗ України"
}

\begin{abstract}
У статті досліджено функціональний стан серцево-судинної системи в учнів молодшого шкільного віку з порушеннями постави в сагітальній площині та проведено оцінку ефективності розробленої програми для корекції даних порушень.
\end{abstract}

\section{FUNCTIONAL CHANGES OF CARDIOVASCULAR ACTIVITY IN STUDENTS WITH POSTURE DISABILITIES BEFORE AND AFTER CORRECTION}

\author{
T. P. Andrukhiv, S. O. Konovalenko \\ Chortkiv Communal Central District Hospital \\ SHEI «Ternopil State Medical University by I. Ya. Horbachevsky of MPH of Ukraine»
}

The article examines the functional state of the cardiovascular system in junior pupils with impaired posture in the sagittal plane and evaluates the effectiveness of programs, designed to correct these violations.

Вступ. За даними Міністерства охорони здоров'я Укра ни у 40-50\% дітей шкільного віку спостерігається відхилення в розвитку опорно-рухового апарату. Багато в чому це пов'язано 3 дефіцитом рухово активності. 3 перших років навчання в школі рухова активність знижується на 50 \% і надалі продовжує неухильно падати [4].

Порушення постави частіше всього виникають в шкільному віці, особливо в періоди прискореного росту скелета дітей (періоди витягування), але, оскільки сьогоднішнє покоління дітей багато часу проводить біля телевізора і комп'ютера, постава у дітей порушується вже в дошкільному віці. Дитина з порушеною поставою відрізняється не тільки непривабливим зовнішнім виглядом, ця дитина, як правило, мало часу проводить на свіжому повітрі, вона малорухома і неправильно харчується, часто хворіє простудними захворюваннями. Порушення постави - це хвороба, але дитина з порушеною поставою перебуває у групі ризику щодо розвитку ортопедично патологі хребта, захво-

(․ Т. П. Андрухів, С. О. Коноваленко, 2015 рювань серцево-судинно системи, органів дихання, травлення і т. д. [1, 3, 8].

Виявлення причин порушення постави та корекція $є$ головними завданнями у профілактиці та медичному контролю на уроках фізично культури.

Основна частина. Хребет людини є центральною віссю тіла, складною за конструкцією системою, що виконує дуже важливі функці : $\epsilon$ опорою тіла в положенні стоячи, сидячи; служить для прикріплення кісток і м'язів верхніх і нижніх кінцівок; захищає спинний мозок від пошкоджень, $є$ складовою частиною задніх стінок грудно, черевно та тазово порожнин, бере участь у русі голови і тулуба. Навантаження на різні сегменти хребетного стовпа зростають у міру наближення до його основи, яким $\epsilon$ таз. Щоб впоратися зі сво ми функціями, хребет повинен одночасно бути міцним і еластичним, а також рухливим у багатьох площинах.

У сагітальній площині хребта $\epsilon$ шийний та поперековий лордози, а в грудному та крижовому - кіфози. Щодо викривлень у фронтальній площині, то питання залишається дискусійним, але багато авторів схиляються до думки про 
наявність фізіологічних сколіозів: у шийному й поперековому відділах хребта вправо, а в грудному - вліво [3]. За таких умов амортизуюча Функція хребта як цілісного органа найбільш ефективна [3, 5].

Відповідно до форми хребта розміщені інші органи. Зміна форми хребта призводить до порушень структури організму як єдиного цілого, у вигляді зміни синтопі органів, деформаці самих органів, вивідних протоків, нервових і судинних структур внутрішніх органів.

Шлях передачі патологічно інформаці на інші органи й системи може приховуватись у змінах вегетативно сегментарно нервово системи, особливо тіє частини, що легко травмується при захворюваннях хребта. До цих відділів можна віднести вегетативні ядра бічних рогів спинного мозку, вегетативні волокна, що проходять у складі спинномозкових нервів у міжхребцевих отворах, а також ганглі симпатичного вегетативного ланцюга, який розташований по ходу всього хребта від другого шийного до першого куприкового хребців [2, 4, 6].

При зміні хребців або міжхребцевих дисків, суглобів, зв'язок виникають умови для подразнення чи навіть компресі відповідних вегетативних структур сегмента, і ця патологія буде передаватися на інші органи чи анатомічні структури, що пов'язані з ушкодженим сегментом [7].

Прикладом вертеброгенних впливів на органи й системи може бути виникнення аритмій серця при подразненні вегетативних шийних ганглі в, зокрема зірчастого [7, 8].

У літературі $\epsilon$ повідомлення, що у дітей з функціональними порушеннями постави відбуваються зміни зі сторони серця та магістральних судин. Це призводить до функціональних змін, в основному, в правих відділах серця та судинах малого кола кровообігу, а саме: до утруднення кровотоку в системі легенево артері, підвищення венозного тиску, перевантаження, гіпертрофі, а надалі - до розширення право половини серця [9, 10].

Незважаючи на численні дослідження, дані про стан серцево-судинно системи у дітей 3 функціональними порушеннями постави в літературі мають фрагментарний характер.

Метою даного дослідження було вивчення функціонального стану серцево-судинно системи в учнів молодшого шкільного віку з порушеннями постави у сагітальній площині та оцінити вплив розроблено програми для корекці даних порушень.

Базою у даному дослідженні була Чортківська ЗОШ № 2 Тернопільсько області. Дослідження проводилося з учнями початкових класів. В експериментальну групу ввійшли 42 учні віком 9-10 років. Всі діти були розподілені на дві групи: 1 група - діти з нормальною поставою у кількості 22 учні, 2 група - діти з відхиленнями у поставі - 20 учнів. Робота проводилася у три етапи. На першому етапі дослідження була проведена робота з медичним працівником, з вивчення стану постави у дітей за даними медогляду. На другому етапі дослідження були підібрані методики для виявлення порушень постави. На третьому етапі дослідження проводився порівняльний аналіз до і після експерименту.

Діти з функціональними порушеннями постави скаржилися на біль у ділянці серця, частіше колючого та ниючого характеру, переважно пов'язаного з психоемоційними навантаженнями, серцебиття, мав місце головний біль, слабість, втомлюваність. При об'єктивному обстеженні зміщення перкуторних границь серця не виявлено. Ослаблення серцевих тонів при аускультаці виявлено у 5 \% дітей, акцент другого тону над легеневою артерією - у одніє дитини. У $10 \%$ обстежених вислуховується функціональний систолічний шум над ділянкою серця, з локалізацією на верхівці та в V точці.

3 дітьми проводилися заняття три рази на тиждень для виправлення порушень постави, які вимагають систематичного виконання. Робота проходила в групі й індивідуально. На заняттях лікувально гімнастики для виправлення порушень постави проводилися такі вправи: для вироблення відчуття правильно постави; для плоско спини; для кругло спини; для опукло спини.

Через 2 місяці проводилося повторне обстеження учнів із порушеннями постави в сагітальній площині, результати обстеження порівнювали з результатами обстеження до корекці .

Показники функціонального стану системи кровообігу обстежених учнів наведено в таблицях $1,2$.

Таблиця 1. Параметри функціонального стану органів кровообігу обстежених учнів після проведеної корекції (юнаки), ( $\left.M_{ \pm} m\right)$

\begin{tabular}{|c|l|l|l|}
\hline \multicolumn{2}{|c|}{ Параметри } & \multicolumn{1}{|c|}{ Група 1 } & \multicolumn{1}{c|}{ Група 2 } \\
\hline \multirow{2}{*}{ ЧСС,$y \partial . / x в$} & до & $84,1 \pm 2,62$ & $86,3 \pm 2,8$ \\
\cline { 2 - 4 } & після & $84,8 \pm 2,3$ & $75,4 \pm 1,5$ \\
\hline \multirow{2}{*}{ САТ, мм pm. cm. } & до & $128,3 \pm 3,6$ & $128,71 \pm 3,6$ \\
\cline { 2 - 4 } & після & $127,4 \pm 2,3$ & $124,4 \pm 2,0$ \\
\hline \multirow{2}{*}{ ДАТ, мм pm. cm. } & до & $72,5 \pm 1,6$ & $75,2 \pm 1,8$ \\
\cline { 2 - 4 } & після & $73,1 \pm 1,2$ & $72,0 \pm 1,5$ \\
\hline
\end{tabular}


Таблиця 2. Параметри функціонального стану органів кровообігу обстежених учнів після проведеної корекції (дівчата), $\left(M_{ \pm} m\right)$

\begin{tabular}{|l|l|l|l|}
\hline \multicolumn{2}{|c|}{ Параметри } & \multicolumn{1}{c|}{ Група 1 } & \multicolumn{1}{c|}{ Група 2 } \\
\hline \multirow{2}{*}{ ЧСС,$y \partial . / x \varepsilon$} & до & $86,4 \pm 2,5$ & $87,4 \pm 2,3$ \\
\cline { 2 - 4 } & після & $83,2 \pm 1,2$ & $72,4 \pm 1,0$ \\
\hline \multirow{2}{*}{ САТ, мм pm. cm. } & до & $119,0 \pm 2,3$ & $121,2 \pm 2,1$ \\
\cline { 2 - 4 } & після & $124,0 \pm 2,0$ & $122,0 \pm 1,8$ \\
\hline \multirow{2}{*}{ ДАТ, мм pm. cm. } & до & $73,4 \pm 2,1$ & $71,4 \pm 1,8$ \\
\cline { 2 - 4 } & після & $74,9 \pm 0,8$ & $73,1 \pm 1,8$ \\
\hline
\end{tabular}

Після проведено корекці у дітей з функціональними порушеннями скарг не виявлено. Відмічена підвищена працездатність та самопочуття учнів. Достовірне покращення результатів

\section{ЛIТЕРАТУРА}

1. Гапіздра А. А. Взаємозв' язок функціонапьних порушень постави і фрізичної підготовленості школярів / А. А. Галіздра / / Теорія та методика фрізичного виховання. - Х. : ОВС, 2005. - № 2(18). - С. 25-27.

2. Кашуба В. А. Биомеханика осанки / В. А. Кашуба. -К. : Олимп. л-ра, 2003. -279 с.

3. Котешева И. А. Нарушения осанки. Лечение и проффилактика / И. А. Котешева. - М. : Эксмо, 2004. 208 c.

4. Клинические, функциональные и инструментальные методы исследования в физической реабилитации / под ред. В. К. Ярового. - Севастополь : [6. и.], 2004. - 126 с.

5. Медицинская реабилитация / под ред. В. А. Епифранова. - М. : МЕДпресс-инорорм, 2005. - С. 161-236.

6. Белова А. Н. Нейрореабилитация: руководство дпя врачей / А. Н. Белова. - М. : Антидор, 2003. - 735 с. обстеження свідчить про позитивний вплив програми корекці порушень постави на функціональну підготовленість організму.

Висновки. Після проведеного обстеження виявлено Функціональні зміни у дітей з порушеннями постави в сагітальній площині та відзначено сприятливий вплив корекці на Функціональні показники серцево-судинно системи, що аргументовано на підставі вірогідного зменшення ЧСС у споко, а також покращення показників артеріального тиску. Отже, тривале впровадження програми корекці постави сприятливо позначилося на функціонуванні серцево-судинно системи, про що свідчать усунення суб'єктивних та об'єктивних ознак та значне підвищення рівня працездатHOCTi.

7. Героева И. Б. Вертеброгенный болевой синдром / И. Б. Героева / / Медицинская реабипитация / под ред. В. А. Епифанова. - М. : МЕДпресс-инфоорм, 2006. C. 191-208.

8. Колісник П. Ф. Особливості патогенезу та лікування вертеброгенних аритмій серця / П. Ф. Колісник // Вісник Вінницького державного медичного університету. - 2000. - № 2. - С. 475-477.

9. Кузнецов В. Ф. Справочник по вертеброневрологии: клиника, діагностика / В. Ф. Кузнецов. - Мн. : Беларусь, 2000. - 351 с.

10. Ошевенский Л. В. Изучение состояния здоровья человека по функциональньм показателям организма : метод. рек. / Л. В. Ошевенский, Е. В. Крылова, Е. А. Уланова. - М : [б. и.], 2007. - 67 с. 